\title{
CHEMICAL MODIFICATION OF HERBIMYCIN A \\ SYNTHESIS AND IN VIVO ANTITUMOR ACTIVITIES \\ OF HALOGENATED AND OTHER RELATED \\ DERIVATIVES OF HERBIMYCIN A
}

\author{
Kiyoshi Shibata and Sadayoshi Satsumabayashi \\ Nippon Dental University, \\ Chiyoda-ku, Tokyo 102, Japan \\ Hiroshi Sano, Kanki Komiyama, Akira Nakagawa \\ and SATOSHI ŌMURA \\ The Kitasato Institute and School of Pharmaceutical Sciences, \\ Kitasato University, \\ Minato-ku, Tokyo 108, Japan \\ (Received for publication September 4, 1985)
}

\begin{abstract}
Several halogenated and other related derivatives of herbimycin A have been synthesized and evaluated in vivo for their activities against Ehrlich ascites carcinoma. Some of these derivatives show higher activities than herbimycin A. Among them the derivatives modified at the 4, 5, 6, and 7-positions of the ansa chain showed particularly high activities.
\end{abstract}

Herbimycin $\mathrm{A}^{1)}$, a new ansamycin antibiotic isolated from the culture broth of Streptomyces hygroscopicus AM-3672, shows herbicidal, anti-tobacco mosaic virus and antitumor activities ${ }^{2}$.

The structure of herbimycin $\mathrm{A}$ has been confirmed as a benzoquinoid type ansamycin antibiotic ${ }^{3,4)}$, which is similar to the other antitumor antibiotics, geldanamycin ${ }^{5,8)}$, and macbecin ${ }^{7,8)}$. In this paper, we wish to describe the synthesis of halogenated and other related derivatives of herbimycin $\mathrm{A}$ and their in vivo activities against Ehrlich ascites carcinoma.

The hydrogen at the 19-position of herbimycin A is easily substituted by a nucleophile. For example, treatment of herbimycin A with pyridinium hydrobromide perbromide ${ }^{9)}$ (also, pyridinium hydrobromide perbromide is an electrophilic reagent which attacks nucleophilic centers in molecules) in a mixture of chloroform and methanol at $-35^{\circ} \mathrm{C}$ gave 19-bromoherbimycin $\mathrm{A}(\mathbf{1})$ and an unexpected product, 9,19-dibromo-7-decarbamoyl-7,8-O-carbonyl-8,9-dihydro-8-hydroxyherbimycin A (2) in 85 and $5 \%$ yields, respectively. The yield of 2 was $15 \%$ when the reaction was performed at $-10^{\circ} \mathrm{C}$.

The structure of 1 was confirmed from a disappearance of the 19-proton signal observed in herbimycin $\mathrm{A}$ and a downfield shift $(\Delta 8.1 \mathrm{ppm})$ of the 19-carbon signal $\left(\delta_{\mathrm{C}} 121.0\right)$ in the NMR spectrum, in addition to the indication of the substitution of a hydrogen atom by a bromine one in its mass spectrum. The structure of $\mathbf{2}$ was evidenced from the following data; the characteristic absorption of fivemembered cyclic carbonate at $1760 \mathrm{~cm}^{-1}$, in the IR spectrum, the disappearance of 19-proton signal in the ${ }^{1} \mathrm{H}$ NMR and the existence of only one nitrogen atom in the elemental analysis. The ${ }^{13} \mathrm{C} \mathrm{NMR}$ spectrum showed the disappearance of olefinic carbon signals at 8 and 9-positions which were observed in the spectra of herbimycin A and 1. Further, two new carbon signals at $\delta 85.9$ (quarternary) and 67.8 (tertiary) were assigned to the carbons attached to oxygen and bromine, respectively. Treatment of $\mathbf{2}$ with tert-BuSnH ${ }^{10)}$ in toluene at refluxing temperature afforded debrominated product (3). 

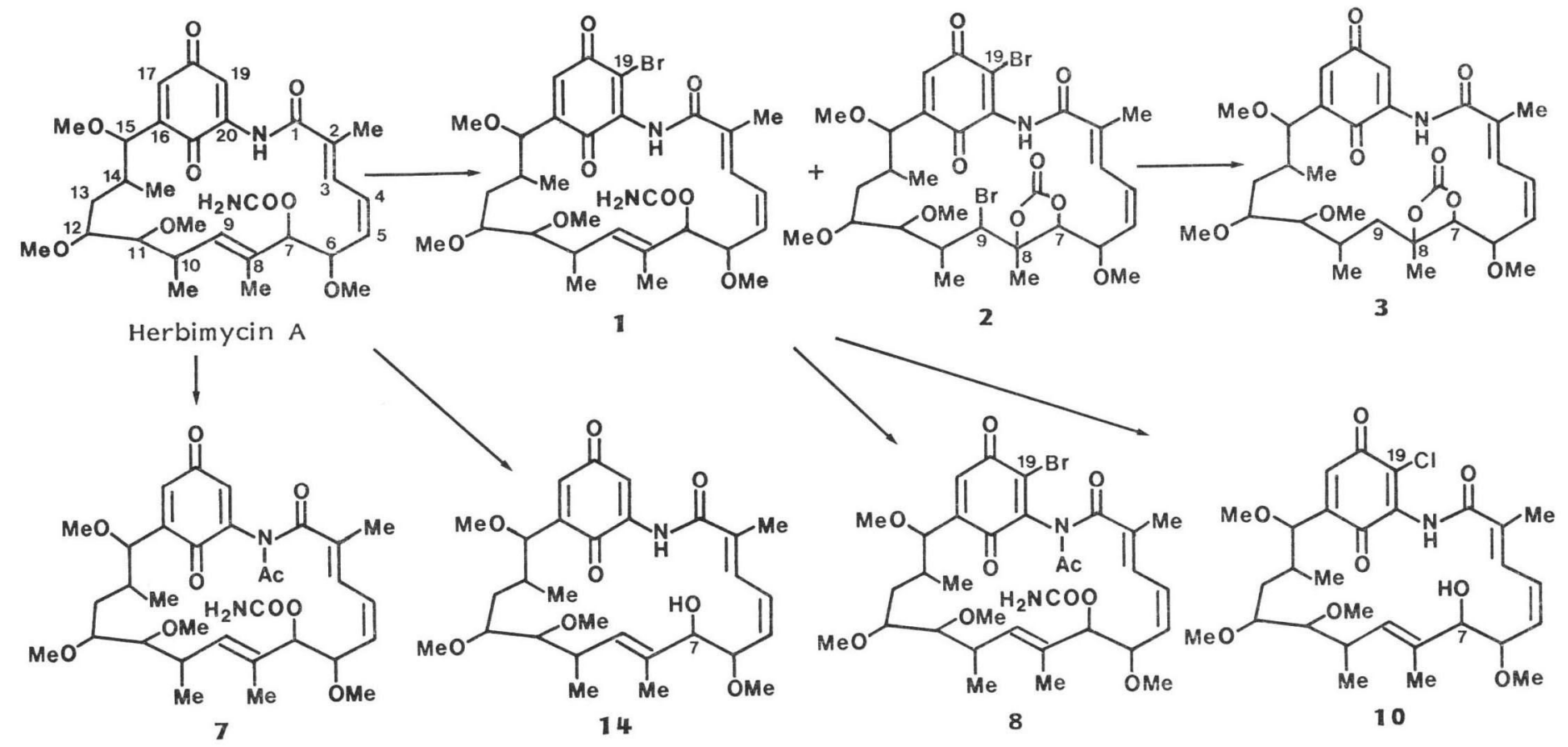

章

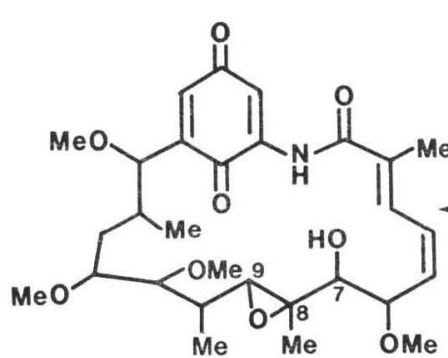

15

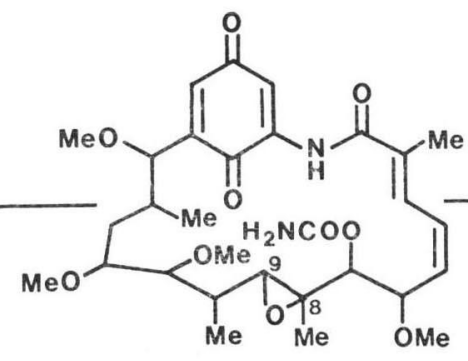

5
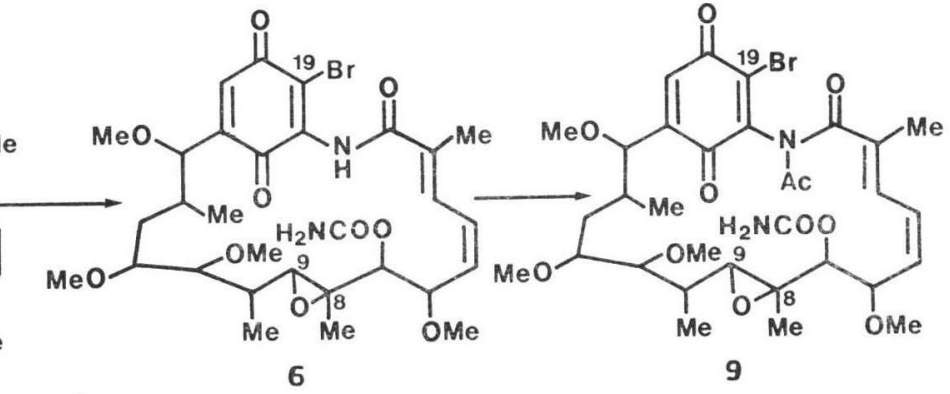

 
In the ${ }^{13} \mathrm{C}$ NMR spectrum of $\mathbf{3}$, the signal at $\delta$ 67.8 observed in 2 disappeared and the new singal at $\delta 34.0$, assignable to 9-methylene carbon by $\mathrm{C}-\mathrm{H}$ selective decoupling and proton homo decoupling techniques was observed, confirming 7,8-O-carbonyl-8,9-dihydro structure for 2 . The transformation from 2 to 3 also supported the structure of 2.

We have assigned 7,9-cyclic carbamate for<smiles>COC(C)C(C)C(/C=C\C=C(/C)C(=O)NC1=CC(=O)C=C(C(OC)C(C)CC(OC)C(OC)C(C)C)C1OC(=O)O)OC</smiles>
compound 4 in a previous report ${ }^{11}$. However, in the course of the structure determination of 2 and 3, compound 4 was revised to be 7,8-cyclic carbonate structure, as shown above.

8,9-Epoxyherbimycin A (5) ${ }^{11)}$, which was obtained on treatment of $\mathbf{1}$ with $m$-chloroperbenzoic acid, was reacted with pyridinium hydrobromide perbromide in the similar manner described above to give 19-bromo-8,9-epoxyherbimycin A (6) as a sole product. Treatment of herbimycin A, 1 and 6 with silver acetate in acetic anhydride ${ }^{12)}$ gave each $N$-acetyl derivative (7 9) in which these structures were confirmed from the IR (disappearance of amide absorption at about $1550 \mathrm{~cm}^{-1}$ observed in mother compounds) and NMR ( $N$-acetyl methyl at about $2.4 \mathrm{ppm})$ spectra.

Treatment of $\mathbf{1}$ with copper chloride in $N, N$-dimethylformamide at $90^{\circ} \mathrm{C}^{13)}$ resulted in a substitution of the bromine atom at 19-position by chlorine accompanying decarbamoylation, to afford 19-chloro-7-decarbamoylherbimycin A (10). Since this reaction seemed to be useful as decarbamoylation procedure in nonaqueous conditions, it was applied to herbimycin A and $\mathbf{5}$ to give decarbamoyl derivatives 14 and $\mathbf{1 5}$, respectively.

Boron trichloride is well known to react with ether group giving the corresponding alkyl chloride

Scheme 2.

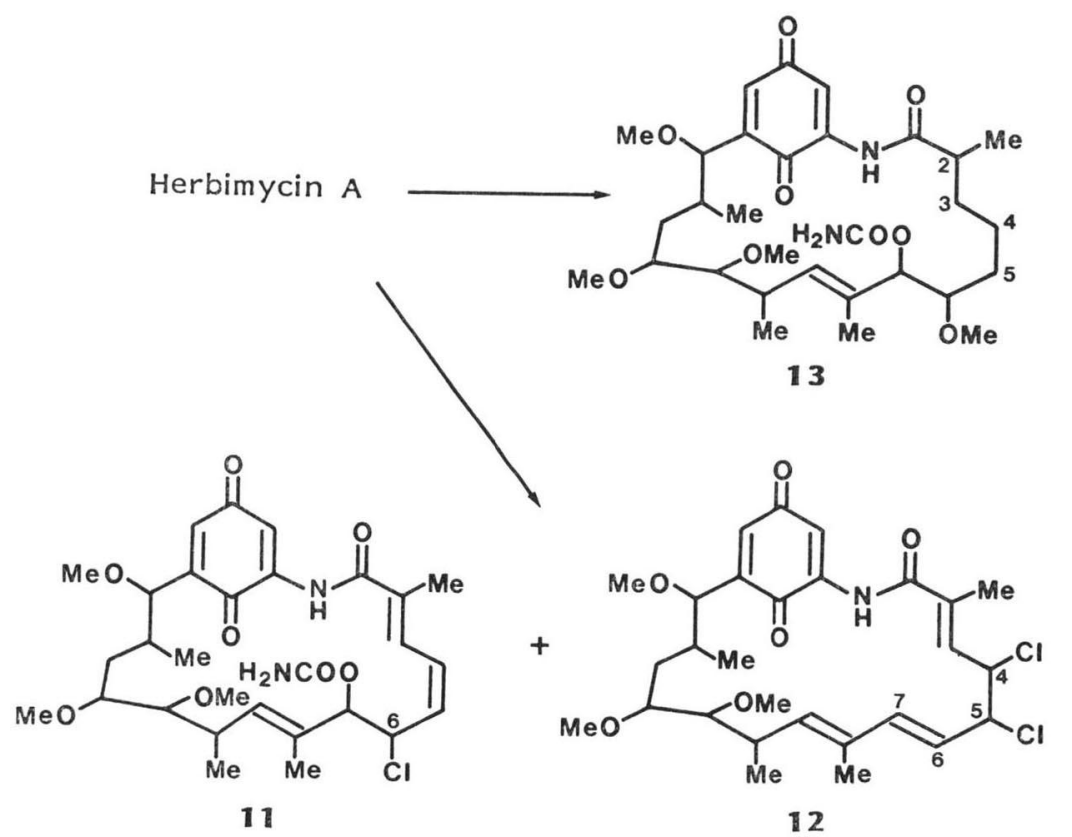


Table 1. ${ }^{13} \mathrm{C}$ NMR chemical shifts for herbimycin A derivatives.

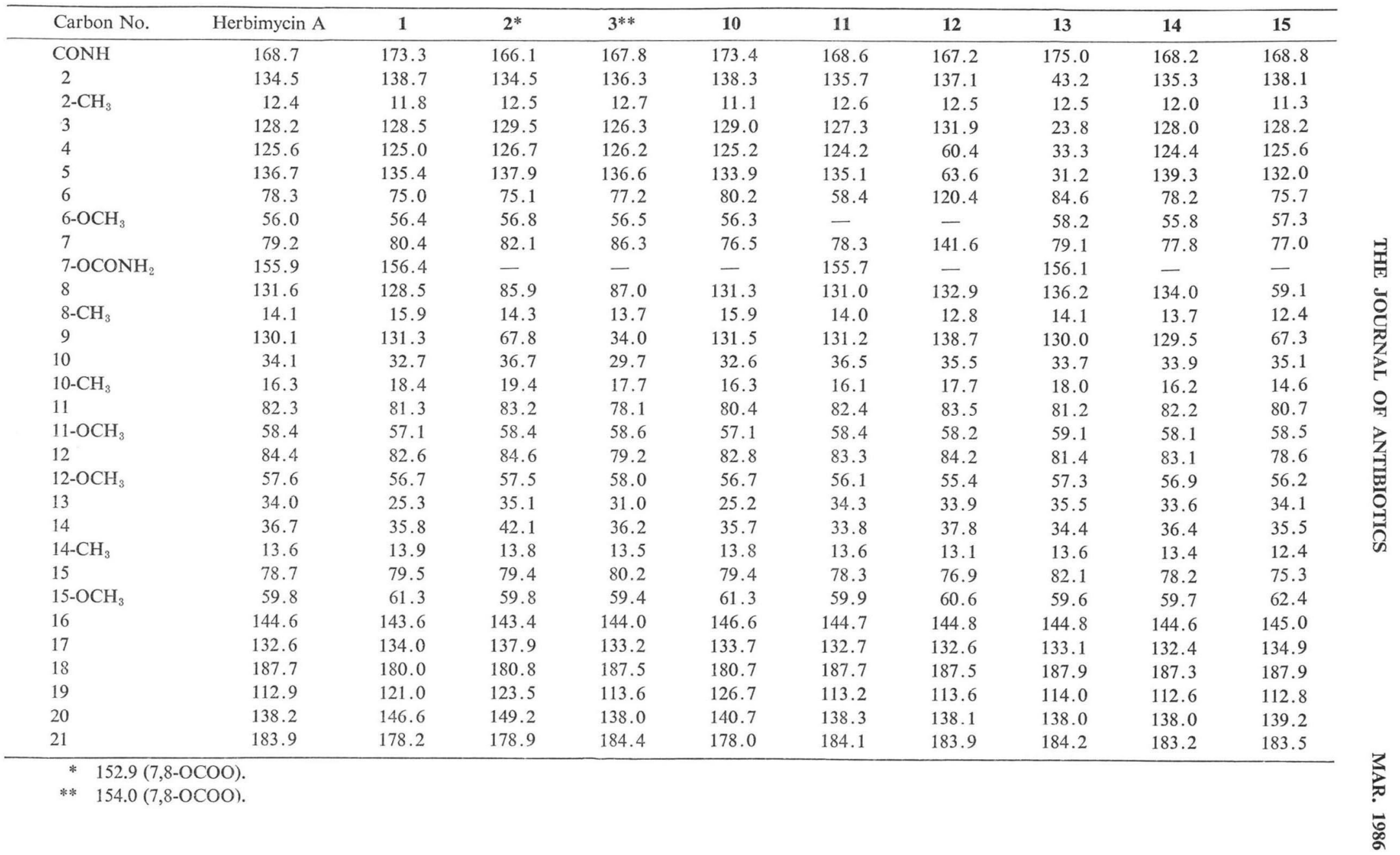


and alcohol ${ }^{14)}$. Treatment of herbimycin A with trichloroboran $\left(\mathrm{BCl}_{3}\right)$ in chloroform at $-40^{\circ} \mathrm{C}$ for 20 hours gave 6-chloro-6-demethoxyherbimycin A (11) and 4,5-dichloro-4,5-dihydro-7-decarbamoyloxy-6-demethoxy-6-enoherbimycin A (12) in 35 and $20 \%$ yields, respectively. The ${ }^{13} \mathrm{C}$ NMR spectrum of $\mathbf{1 1}$ indicated the substitution of a chlorine atom for the methoxy group at the 6-position. Consequently, the signal for the 6-position carbon atom $(\delta 58.4)$ was observed to shift upfield ( $\Delta 19.9$ ppm) in comparison with that of herbimycin A supporting the structure of 11 . The structure of 12 was also assigned by proton homo de-
Scheme 3.

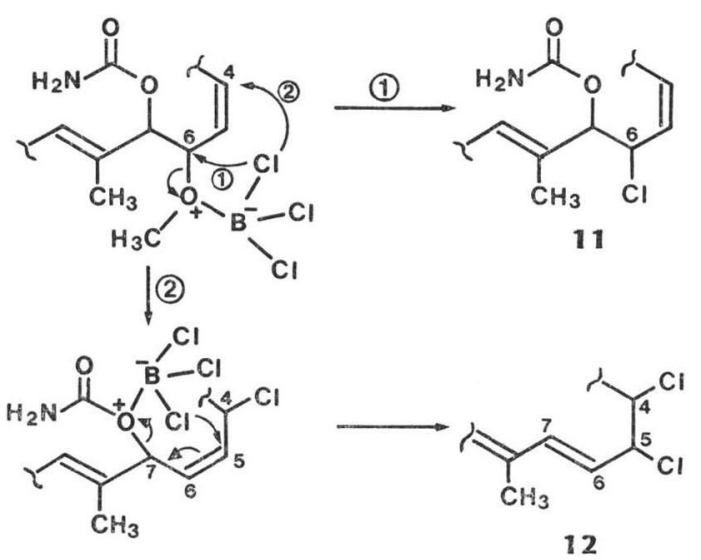
coupling and $\mathrm{C}-\mathrm{H}$ selective decoupling techniques. These spectral data showed the disappearance of the carbamoyl carbon at the 7-position and the methoxy methyl at the 6-position and formation of additional two olefinic carbon signals at $\delta 120.4$ and 141.6.

Compounds 11 and 12 seemed to be produced through intramolecular attack of a chlorine atom of $\mathrm{BCl}_{3}$ bonded to 6-methoxy or 7-carbamoyl oxygen as shown in Scheme 3. Although the stereochemistry of $\mathbf{1 1}$ and $\mathbf{1 2}$ has not been determined yet, the reaction seems to proceed stereo-selectively.

The 4,5-saturated derivative (12) of herbimycin A was of interest because the antitumor activity was superior as described below. Thus, 2,3,4,5-tetrahydroherbimycin A (13) was synthesized by catalytic hydrogenation.

The ${ }^{13} \mathrm{C}$ NMR chemical shift values for herbimycin A derivatives were summarized in Table 1.

\section{Antitumor Activities}

Antitumor activities $(\mathrm{T} / \mathrm{C} \%$ ) at optimal doses of herbimycin A derivatives against Ehrlich ascites carcinoma are given in Table 2. Among the various derivatives, the halogenated compounds $(\mathbf{1}, \mathbf{1 1}$

Table 2. Antitumor activity of herbimycin A derivatives against Ehrlich ascites carcinoma.

\begin{tabular}{ccccc}
\hline Compound & $\begin{array}{c}\text { Total dose } \\
(\mathrm{mg} / \mathrm{kg})\end{array}$ & $\begin{array}{c}\text { Dose } \\
(\mathrm{mg} / \mathrm{kg} \times \text { day })\end{array}$ & $\begin{array}{c}\mathrm{T} / \mathrm{C} \\
(\%)\end{array}$ & $\begin{array}{c}\text { Number of* } \\
\text { survival/total }\end{array}$ \\
\hline $\mathbf{1}$ & 250 & $50.0 \times 5$ & 190 & $4 / 4$ \\
$\mathbf{2}$ & 125 & $25.0 \times 5$ & 134 & $1 / 4$ \\
$\mathbf{3}$ & 250 & $50.0 \times 5$ & 150 & $2 / 4$ \\
$\mathbf{6}$ & 250 & $50.0 \times 5$ & 144 & $1 / 4$ \\
$\mathbf{7}$ & 125 & $25.0 \times 5$ & 89 & $0 / 4$ \\
$\mathbf{8}$ & 62.5 & $12.5 \times 5$ & 91 & $0 / 4$ \\
$\mathbf{9}$ & 31.3 & $6.3 \times 5$ & 92 & $1 / 4$ \\
$\mathbf{1 0}$ & 250 & $50.0 \times 5$ & 129 & $4 / 4$ \\
$\mathbf{1 1}$ & 125 & $25.0 \times 5$ & 200 & $4 / 4$ \\
$\mathbf{1 3}$ & 250 & $50.0 \times 5$ & 215 & $3 / 4$ \\
$\mathbf{1 4}$ & 125 & $25.0 \times 5$ & 193 & $3 / 4$ \\
$\mathbf{1 5}$ & 250 & $50.0 \times 5$ & 200 & $2 / 4$ \\
Herbimycin A & 125 & $25.0 \times 5$ & 146 & $1 / 4$ \\
Geldanamycin & 6.3 & $1.3 \times 5$ & 126 & $1 / 4$ \\
\hline
\end{tabular}

* Number of surviving mice at day 31 . 
and 12), the tetrahydro derivative (13) and decarbamoylherbimycin A (14) are notable for showing higher antitumor activity than that of herbimycin A. The carbamoyl group seems not to be necessary for activity because decarbamoyl derivatives $\mathbf{1 4}$ and $\mathbf{1 5}$ showed either similar or higher activity than the corresponding mother compounds.

The high activity of 4,5-dichloro (12) and 2,3,4,5-tetrahydro (13) derivatives indicate the possibility of additional improvement of activity by further chemical modification at the 4 and 5-position of herbimycin A. The acetylation of amide nitrogen in $7 \sim 9$ resulted in a decrease in activity.

\section{Experimental}

NMR spectra were measured with a Jeol FX-90 and Bruker AM 400 spectrometer in $\mathrm{CDCl}_{3}$ solution. Mass spectra were obtained with a Jeol D-100 and DX-300 spectrometer at $20 \mathrm{eV}$. Optical rotations were measured with a Jasco DIP-181 polarimeter. Thin-layer chromatography (TLC) was performed on pre-coated plates, Merck Kiesel gel $60 \mathrm{~F}_{254}$ with benzene- $\mathrm{Me}_{2} \mathrm{CO}, 7: 3$. Silica gel column chromatography was performed with Merck Kiesel gel 60 .

\section{Antitumor Activity}

Ehrlich carcinoma cells $\left(2.5 \times 10^{8}\right)$ were inoculated ip to $d d \mathrm{Y}$ mice on day 0 . Mice received various dose $(<250 \mathrm{mg} / \mathrm{kg})$ of herbimycin A derivatives for 5 successive days. Antitumor activity was expressed as $\mathrm{T} / \mathrm{C}(\%)$ at the optimal dose for each derivative: " $\mathrm{T}$ " is median survival days of the treated group and " $\mathrm{C}$ " is that of the control group.

19-Bromoherbimycin A (1) and 9,19-Dibromo-7-decarbamoyl-7,8-O-carbonyl-8,9-dihydro-8hydroxyherbimycin A (2)

To a solution of herbimycin $\mathrm{A}(1.0 \mathrm{~g})$ in $\mathrm{CHCl}_{3}-\mathrm{MeOH}, 1: 1,(20 \mathrm{ml})$, pyridinium hydrobromide perbromide $(500 \mathrm{mg})$ was added under cooling at $-35^{\circ} \mathrm{C}$ and held for 6 hours. The reaction mixture was poured into $\mathrm{H}_{2} \mathrm{O}(100 \mathrm{ml})$ and extracted with $\mathrm{CHCl}_{3}(100 \mathrm{ml} \times 2)$. The $\mathrm{CHCl}_{3}$ solution was washed with $5 \%$ aq $\mathrm{Na}_{2} \mathrm{~S}_{2} \mathrm{O}_{3}$ and satd solution of $\mathrm{NaCl}$, dried over anhydrous $\mathrm{Na}_{2} \mathrm{SO}_{4}$ and evaporated in vacuo. The residue was chromatographed on a silica gel column with benzene $-\mathrm{Me}_{2} \mathrm{CO}, 8: 2$, to give a yellowish powder of $\mathbf{1}, 968 \mathrm{mg}(85.0 \%)$ and $2,64 \mathrm{mg}(5.0 \%)$.

1: TLC Rf $0.45 ; \mathrm{mp} 178^{\circ} \mathrm{C}(\mathrm{dec}) ;[\alpha]_{D}^{23}+93^{\circ}\left(c 0.5, \mathrm{CHCl}_{3}\right)$; UV $\lambda_{\max }^{\mathrm{MeOH}} \mathrm{nm}(\varepsilon) 258(18,600)$; ${ }^{1} \mathrm{H}$ NMR $\left(\mathrm{CDCl}_{3}\right) \delta 6.92(1 \mathrm{H}, \mathrm{d}, J=0.9 \mathrm{~Hz}, \mathrm{H}-17), 6.42(1 \mathrm{H}, \mathrm{qd}, J=1.1$ and $11.5 \mathrm{~Hz}, \mathrm{H}-3), 6.32(1 \mathrm{H}$, dd, $J=11.5$ and $11.5 \mathrm{~Hz}, \mathrm{H}-4), 5.30(1 \mathrm{H}, \mathrm{dd}, J=10.6$ and $11.5 \mathrm{~Hz}, \mathrm{H}-5), 5.28(1 \mathrm{H}, \mathrm{qd}, J=1.0$ and 9.8 $\mathrm{Hz}, \mathrm{H}-9), 5.03(1 \mathrm{H}, \mathrm{d}, J=9.4 \mathrm{~Hz}, \mathrm{H}-7), 4.49(1 \mathrm{H}, \mathrm{dd}, J=0.9$ and $4.1 \mathrm{~Hz}, \mathrm{H}-15), 4.00(1 \mathrm{H}, \mathrm{dd}, J=$ 9.4 and $10.6 \mathrm{~Hz}, \mathrm{H}-6), 3.18(1 \mathrm{H}, \mathrm{dd}, J=1.8$ and $10.0 \mathrm{~Hz}, \mathrm{H}-11), 2.25(1 \mathrm{H}, \mathrm{m}, \mathrm{H}-10), 1.26(3 \mathrm{H}, \mathrm{d}, J=$ $1.0 \mathrm{~Hz}, 8-\mathrm{CH}_{3}$ ).

Anal Caled for $\mathrm{C}_{30} \mathrm{H}_{41} \mathrm{~N}_{2} \mathrm{O}_{9} \mathrm{Br}$ :

Found:

C 55.20, H 6.34, N 4.29, Br 12.10.

C $54.89, \mathrm{H} 6.32, \mathrm{~N} 4.26, \mathrm{Br} 12.68$.

2: $\quad$ TLC Rf $0.84 ; \mathrm{mp} 132^{\circ} \mathrm{C}(\mathrm{dec}) ;[\alpha]_{\mathrm{D}}^{23}+83^{\circ}\left(c 0.5, \mathrm{CHCl}_{3}\right)$; UV $\lambda_{\max }^{\mathrm{MeOH}} \mathrm{nm}(\varepsilon) 268(18,000) ;{ }^{1} \mathrm{H}$ NMR $\left(\mathrm{CDCl}_{3}\right) \delta 7.28(1 \mathrm{H}, \mathrm{qd}, J=1.2$ and $12.2 \mathrm{~Hz}, \mathrm{H}-3), 6.81(1 \mathrm{H}, \mathrm{d}, J=1.6 \mathrm{~Hz}, \mathrm{H}-17), 4.61(1 \mathrm{H}, \mathrm{d}$, $J=7.3 \mathrm{~Hz}, \mathrm{H}-6), 4.47(1 \mathrm{H}, \mathrm{s}, \mathrm{H}-7), 4.32(1 \mathrm{H}, \mathrm{d}, J=9.4 \mathrm{~Hz}, \mathrm{H}-9), 2.39(1 \mathrm{H}, \mathrm{m}, \mathrm{H}-10), 1.83$ (3H, s, 8- $\mathrm{CH}_{3}$ ).

Anal Calcd for $\mathrm{C}_{30} \mathrm{H}_{38} \mathrm{NO}_{10} \mathrm{Br}_{2}$ : Found:

C 49.24, H 5.38, N 1.92, Br 21.16.

C 48.97, H 5.31, N 1.93, Br 21.69.

7-Decarbamoyl-7,8-O-carbonyl-8,9-dihydro-8-hydroxyherbimycin A (3)

To a solution of $\mathbf{2}(200 \mathrm{mg})$ in toluene $(4 \mathrm{ml})$, tributyltin hydride $(0.80 \mathrm{ml})$ and $\alpha, \alpha^{\prime}$-azobisisobutyronitrile $\left(7.5 \mathrm{mg}\right.$ ) were added and heated at $80^{\circ} \mathrm{C}$ for 3 hours under a nitrogen atmosphere. The reaction mixture was diluted with $\mathrm{CHCl}_{3}(20 \mathrm{ml})$ and washed with $\mathrm{H}_{2} \mathrm{O}$. The $\mathrm{CHCl}_{3}$ solution was dried over $\mathrm{Na}_{2} \mathrm{SO}_{4}$ and evaporated, to give a brown residue, which was chromatographed on a silica gel column with benzene $-\mathrm{Me}_{2} \mathrm{CO}, 10: 1$, giving $135 \mathrm{mg}(86.0 \%)$ of 3 . TLC Rf $0.84 ; \mathrm{mp} 120^{\circ} \mathrm{C}(\mathrm{dec})$; $[\alpha]_{D}^{23}+65^{\circ}\left(c 0.5, \mathrm{CHCl}_{3}\right)$; UV $\lambda_{\max }^{\mathrm{MeOH}} \mathrm{nm}(\varepsilon) 265(17,300)$; high resolution MS 575.272 (Calcd for 
$\left.\mathrm{C}_{30} \mathrm{H}_{41} \mathrm{NO}_{10}: 575.273\right) ;{ }^{1} \mathrm{H}$ NMR $\left(\mathrm{CDCl}_{3}\right) \delta 7.42(1 \mathrm{H}, \mathrm{d}, J=2.5 \mathrm{~Hz}, \mathrm{H}-19), 6.66(1 \mathrm{H}, \mathrm{dd}, J=1.6$ and $2.6 \mathrm{~Hz}, \mathrm{H}-17), 4.32(1 \mathrm{H}, \mathrm{d}, J=7.2 \mathrm{~Hz}, \mathrm{H}-6), 4.28(1 \mathrm{H}, \mathrm{s}, \mathrm{H}-7), 1.55\left(3 \mathrm{H}, \mathrm{s}, 8-\mathrm{CH}_{3}\right), 1.28(1 \mathrm{H}, \mathrm{m}, \mathrm{H}-$ 9a), 0.89 (1H, m, H-9b).

Anal Calcd for $\mathrm{C}_{30} \mathrm{H}_{41} \mathrm{NO}_{10}$ : C 62.58, H 7.18, N 2.43. Found: C $62.36, \mathrm{H} 7.15, \mathrm{~N} 2.40$.

8,9-Epoxy-19-bromoherbimycin A (6)

To a solution of 8,9-epoxyherbimycin $\mathrm{A}^{11)}(5,500 \mathrm{mg})$ in $\mathrm{CHCl}_{3}-\mathrm{MeOH}, 1: 1(10 \mathrm{ml})$, pyridinium hydrobromide perbromide $(250 \mathrm{mg})$ was added and held for 2 hours at room temp. The reaction mixture was treated in a similar manner as with the preparation of $\mathbf{1}$, to give a yellowish powder of $6,480 \mathrm{mg}(85.0 \%)$. TLC Rf $0.40 ; \mathrm{mp} 172^{\circ} \mathrm{C}(\mathrm{dec}) ;[\alpha]_{\mathrm{D}}^{23}+78^{\circ}\left(c 0.5, \mathrm{CHCl}_{3}\right) ; \mathrm{UV} \lambda_{\max }^{\mathrm{MeOH}} \mathrm{nm}(\varepsilon) 262$ $(20,000) ;{ }^{1} \mathrm{H}$ NMR $\left(\mathrm{CDCl}_{3}\right) \delta 6.86(1 \mathrm{H}, \mathrm{d}, J=1.8 \mathrm{~Hz}, \mathrm{H}-17), 6.48(1 \mathrm{H}, \mathrm{dd}, J=11.0$ and $11.0 \mathrm{~Hz}, \mathrm{H}-4)$, $5.73(1 \mathrm{H}, \mathrm{dd}, J=11.0$ and $11.0 \mathrm{~Hz}, \mathrm{H}-5), 4.58(1 \mathrm{H}$, br s, $\mathrm{H}-7), 4.52(1 \mathrm{H}, \mathrm{d}, J=11.0 \mathrm{~Hz}, \mathrm{H}-6), 2.84(1 \mathrm{H}$, dd, $J=3.5$ and $9.0 \mathrm{~Hz}, \mathrm{H}-9), 1.38\left(3 \mathrm{H}, \mathrm{s}, 8-\mathrm{CH}_{3}\right)$.

Anal Calcd for $\mathrm{C}_{30} \mathrm{H}_{41} \mathrm{~N}_{2} \mathrm{O}_{10} \mathrm{Br}$ : C 53.88, H 6.18, N 4.19, Br 11.81.

Found:

C 53.52, H 6.09, N 4.12, Br 12.11.

$N$-Acetylherbimycin A (7)

To a solution of herbimycin A $(250 \mathrm{mg})$ in acetic anhydride $(4 \mathrm{ml})$, silver acetate $(200 \mathrm{mg})$ was added and heated at $90^{\circ} \mathrm{C}$ for 2 days. The reaction mixture was poured into $\mathrm{H}_{2} \mathrm{O}(100 \mathrm{ml})$ and extracted with $\mathrm{CHCl}_{3}(100 \mathrm{ml} \times 2)$. The $\mathrm{CHCl}_{3}$ solution was washed with satd solution of $\mathrm{NaCl}$ and evaporated to give a solid, which was chromatographed on a silica gel column with benzene $-\mathrm{Me}_{2} \mathrm{CO}$, 10: 1 , to give a yellowish powder of $7,190 \mathrm{mg}(71.0 \%)$. TLC Rf $0.45 ; \mathrm{mp} 119^{\circ} \mathrm{C}(\mathrm{dec}) ;[\alpha]_{\mathrm{D}}^{23}+37^{\circ}$ (c 0.5, $\left.\mathrm{CHCl}_{3}\right)$; UV $\lambda_{\max }^{\mathrm{MeOH}} \mathrm{nm}(\varepsilon) 269(21,000) ;{ }^{1} \mathrm{H} \mathrm{NMR}\left(\mathrm{CDCl}_{3}\right) \delta 6.76(1 \mathrm{H}, \mathrm{dd}, J=1.0$ and $1.7 \mathrm{~Hz}$, $\mathrm{H}-17), 6.70(1 \mathrm{H}, \mathrm{d}, J=1.0 \mathrm{~Hz}, \mathrm{H}-19), 6.44(1 \mathrm{H}, \mathrm{dd}, J=11.5$ and $11.6 \mathrm{~Hz}, \mathrm{H}-4), 5.57(1 \mathrm{H}, \mathrm{dd}, J=10.0$ and $11.5 \mathrm{~Hz}, \mathrm{H}-5), 5.10(1 \mathrm{H}, \mathrm{d}, J=6.7 \mathrm{~Hz}, \mathrm{H}-7), 4.05(1 \mathrm{H}, \mathrm{dd}, J=6.7$ and $10.0 \mathrm{~Hz}, \mathrm{H}-6), 2.43(3 \mathrm{H}$, $\left.\mathrm{s}, \mathrm{N}-\mathrm{COCH}_{3}\right), 1.41\left(3 \mathrm{H}, \mathrm{s}, 8-\mathrm{CH}_{3}\right)$.

Anal Calcd for $\mathrm{C}_{32} \mathrm{H}_{44} \mathrm{~N}_{2} \mathrm{O}_{10}$ : C 62.31, H 7.22, N 4.53. Found: C $62.18, \mathrm{H} 7.30, \mathrm{~N} 4.23$.

$\mathrm{N}$-Acetyl-19-bromoherbimycin A (8)

Compound $1(250 \mathrm{mg})$ was treated with acetic anhydride $(4 \mathrm{ml})$ and silver acetate $(200 \mathrm{mg})$ in a similar manner described in the preparation of 7, to give a yellowish powder of $8,135 \mathrm{mg}(47.0 \%)$. TLC Rf $0.40 ; \operatorname{mp~} 135^{\circ} \mathrm{C}(\mathrm{dec}) ;[\alpha]_{D}^{23}+63^{\circ}\left(c 0.5, \mathrm{CHCl}_{3}\right)$; UV $\lambda_{\max }^{\mathrm{MeOH}} \mathrm{nm}(\varepsilon) 272(18,200)$.

Anal Calcd for $\mathrm{C}_{32} \mathrm{H}_{43} \mathrm{~N}_{2} \mathrm{O}_{10} \mathrm{Br}$ : C 55.31, H 6.24, N 4.03, $\mathrm{Br}$ 11.37. Found:

C 55.12, H 6.43, N 3.94, Br 11.83.

$\mathrm{N}$-Acetyl-19-bromo-8,9-epoxyherbimycin A (9)

Compound $6(250 \mathrm{mg})$ was treated with acetic anhydride $(4 \mathrm{ml})$ and silver acetate $(200 \mathrm{mg})$ in a similar manner with the preparation of 7 , to give a yellowish powder of $9,148 \mathrm{mg}(60.0 \%)$. TLC Rf 0.38; $\mathrm{mp} 114^{\circ} \mathrm{C}(\mathrm{dec}) ;[\alpha]_{\mathrm{D}}^{23}+71^{\circ}\left(c 0.5, \mathrm{CHCl}_{3}\right)$; UV $\lambda_{\max }^{\mathrm{MeOH}} \mathrm{nm}(\varepsilon) 260(16,500)$.

Anal Calcd for $\mathrm{C}_{32} \mathrm{H}_{43} \mathrm{~N}_{2} \mathrm{O}_{11} \mathrm{Br}$ : C 54.07, H 6.10, N 3.94, Br 11.11. Found:

C 53.81, H 6.35, N 3.79, Br 11.61.

7-Decarbamoyl-19-chloroherbimycin A (10)

To a solution of $\mathbf{1}(200 \mathrm{mg})$ in $\mathrm{DMF}(3 \mathrm{ml}), \mathrm{CuCl}(100 \mathrm{mg})$ was added and heated at $90^{\circ} \mathrm{C}$ for 20 hours. The reaction mixture was poured into $\mathrm{H}_{2} \mathrm{O}(100 \mathrm{ml})$ and extracted with $\mathrm{CHCl}_{3}(100 \mathrm{ml} \times$ 2). The $\mathrm{CHCl}_{3}$ solution was dried over $\mathrm{Na}_{2} \mathrm{SO}_{4}$ and evaporated to give a powder, which was chromatographed on a silica gel column with benzene $-\mathrm{Me}_{2} \mathrm{CO}, 10: 1$, to give a yellowish powder of 10, $155 \mathrm{mg}(91.0 \%)$. TLC Rf $0.55 ; \mathrm{mp} 176^{\circ} \mathrm{C}(\mathrm{dec}) ;[\alpha]_{\mathrm{D}}^{23}+49^{\circ}\left(c 0.5, \mathrm{CHCl}_{3}\right) ; \mathrm{UV} \lambda_{\max }^{\mathrm{MeOH}} \mathrm{nm}(\varepsilon) 251$ (16,000); high resolution MS 565.244 (Calcd for $\left.\mathrm{C}_{28} \mathrm{H}_{40} \mathrm{NO}_{8} \mathrm{Cl}: 565.244\right) ;{ }^{1} \mathrm{H}$ NMR $\left(\mathrm{CDCl}_{3}\right) \delta 6.86$ $(1 \mathrm{H}, \mathrm{d}, J=1.0 \mathrm{~Hz}, \mathrm{H}-17), 5.27(1 \mathrm{H}, \mathrm{dd}, J=10.5$ and $11.6 \mathrm{~Hz}, \mathrm{H}-5), 5.14(1 \mathrm{H}, \mathrm{qd}, J=1.1$ and $10.6 \mathrm{~Hz}$, $\mathrm{H}-9), 4.48(1 \mathrm{H}, \mathrm{dd}, J=1.0$ and $4.9 \mathrm{~Hz}, \mathrm{H}-15), 3.85(1 \mathrm{H}, \mathrm{dd}, J=9.2$ and $10.5 \mathrm{~Hz}, \mathrm{H}-6), 3.78(1 \mathrm{H}, \mathrm{d}$, $J=9.2 \mathrm{~Hz}, \mathrm{H}-7), 2.29(1 \mathrm{H}, \mathrm{m}, \mathrm{H}-10), 1.29\left(3 \mathrm{H}, \mathrm{d}, J=1.1 \mathrm{~Hz}, 8-\mathrm{CH}_{3}\right)$.

Anal Calcd for $\mathrm{C}_{29} \mathrm{H}_{40} \mathrm{NO}_{8} \mathrm{Cl}$ : C 61.57, H 7.13, N 4.95, Cl 6.18. Found: 
6-Chloro-6-demethoxyherbimycin A (11) and 4,5-Dichloro-4,5-dihydro-7-decarbamoyloxy-6demethoxy-6-enoherbimycin A (12)

To a solution of herbimycin $\mathrm{A}(1.0 \mathrm{~g})$ in $\mathrm{CHCl}_{3}(10 \mathrm{ml}), 5 \%$ solution of $\mathrm{BCl}_{3}(5 \mathrm{ml})$ was added under cooling at $-40^{\circ} \mathrm{C}$ and held at $-40^{\circ} \mathrm{C}$ for 20 hours. The reaction mixture was poured gradually into ice-water $(100 \mathrm{ml})$ and extracted with $\mathrm{CHCl}_{3}(100 \mathrm{ml} \times 3)$. The $\mathrm{CHCl}_{3}$ solution was dried $\mathrm{Na}_{2} \mathrm{SO}_{4}$ and evaporated to give a residue, which was chromatographed on a silica gel column with benzene $\mathrm{Me}_{2} \mathrm{CO}, 10: 1$, to give a yellowish powder of 11, $360 \mathrm{mg}(35.0 \%)$ and 12, $227 \mathrm{mg}(21.0 \%)$.

11: TLC Rf $0.63 ; \mathrm{mp} 188^{\circ} \mathrm{C}(\mathrm{dec}) ;[\alpha]_{\mathrm{D}}^{23}+54^{\circ}\left(c 0.5, \mathrm{CHCl}_{3}\right)$; UV $\lambda_{\max }^{\mathrm{MeOH}} \mathrm{nm}(\varepsilon) 232(18,500)$; high resolution MS 578.239 (Calcd for $\mathrm{C}_{28} \mathrm{H}_{39} \mathrm{~N}_{2} \mathrm{O}_{8} \mathrm{Cl}$ : 578.239); ${ }^{1} \mathrm{H}$ NMR $\left(\mathrm{CDCl}_{3}\right) \delta 7.23(1 \mathrm{H}, \mathrm{d}, J=2.3$ $\mathrm{Hz}, \mathrm{H}-19), 6.60(1 \mathrm{H}$, dd, $J=2.3$ and $3.0 \mathrm{~Hz}, \mathrm{H}-17), 5.89(1 \mathrm{H}, \mathrm{dd}, J=7.6$ and $11.6 \mathrm{~Hz}, \mathrm{H}-5), 5.80(1 \mathrm{H}$, br s, H-7), $5.51(1 \mathrm{H}, \mathrm{qd}, J=1.0$ and $7.1 \mathrm{~Hz}, \mathrm{H}-9), 5.10(1 \mathrm{H}$, br d, $J=7.6 \mathrm{~Hz}, \mathrm{H}-6), 4.50(1 \mathrm{H}, \mathrm{d}, J=$ $3.0 \mathrm{~Hz}, \mathrm{H}-15), 1.66\left(3 \mathrm{H}, \mathrm{d}, J=1.1 \mathrm{~Hz}, 8-\mathrm{CH}_{3}\right)$.

Anal Calcd for $\mathrm{C}_{29} \mathrm{H}_{39} \mathrm{~N}_{2} \mathrm{O}_{8} \mathrm{Cl}$ : C 60.18, $\mathrm{H} 6.80, \mathrm{~N} 4.84, \mathrm{Cl} 6.05$.

Found:

C $60.01, \mathrm{H} 6.92, \mathrm{~N} 4.71, \mathrm{Cl} 5.89$.

12: TLC Rf $0.80 ; \mathrm{mp} 199^{\circ} \mathrm{C}(\mathrm{dec}) ;[\alpha]_{\mathrm{D}}^{23}+99^{\circ}\left(c 0.5, \mathrm{CHCl}_{3}\right)$; UV $\lambda_{\max }^{\mathrm{MeOH}} \mathrm{nm}(\varepsilon) 271(23,500)$; high resolution MS 553.200 (Calcd for $\mathrm{C}_{28} \mathrm{H}_{37} \mathrm{NO}_{6} \mathrm{Cl}_{2}$ : 553.200); ${ }^{1} \mathrm{H}$ NMR $\left(\mathrm{CDCl}_{3}\right) \delta 7.33(1 \mathrm{H}$, d, $J=2.5 \mathrm{~Hz}, \mathrm{H}-19), 6.63(1 \mathrm{H}, \mathrm{dd}, J=2.0$ and $2.5 \mathrm{~Hz}, \mathrm{H}-17), 6.55(1 \mathrm{H}, \mathrm{d}, J=13.5 \mathrm{~Hz}, \mathrm{H}-7), 5.86(1 \mathrm{H}$, dd, $J=9.8$ and $13.5 \mathrm{~Hz}, \mathrm{H}-6), 4.99(1 \mathrm{H}, \mathrm{dd}, J=2.7$ and $10.6 \mathrm{~Hz}, \mathrm{H}-4), 4.66(1 \mathrm{H}, \mathrm{dd}, J=2.7$ and $9.8 \mathrm{~Hz}$, $\mathrm{H}-5), 1.75\left(3 \mathrm{H}, \mathrm{d}, J=1.3 \mathrm{~Hz}, 8-\mathrm{CH}_{3}\right)$.

Anal Calcd for $\mathrm{C}_{28} \mathrm{H}_{37} \mathrm{NO}_{6} \mathrm{Cl}_{2}$ : C 60.74, $\mathrm{H}$ 6.74, N 2.53, $\mathrm{Cl} 12.64$.

Found:

$\mathrm{C} 60.28, \mathrm{H} 6.98, \mathrm{~N} 2.45, \mathrm{Cl} 12.89$.

\section{2,3,4,5-Tetrahydroherbimycin A (13)}

To a solution of herbimycin A $(250 \mathrm{mg})$ in EtOH $(10 \mathrm{ml}), \mathrm{Pd}-\mathrm{C}(\mathrm{Pd} 10 \%, 50 \mathrm{mg})$ was added and stirred under $\mathrm{H}_{2}$ gas at atmospheric pressure for 1 hour. Solid was removed by filtration and the filtrate was poured into $\mathrm{H}_{2} \mathrm{O}(100 \mathrm{ml})$. The solution extracted with $\mathrm{CHCl}_{3}(100 \mathrm{ml} \times 3)$ and the $\mathrm{CHCl}_{3}$ solution was evaporated to afford the residual solid which was chromatographed on a silica gel column with benzene $-\mathrm{Me}_{2} \mathrm{CO}, 10: 1$, to give a yellowish powder of $13,195 \mathrm{mg}(78.0 \%)$. TLC Rf $0.55 ; \mathrm{mp}$ $208^{\circ} \mathrm{C}(\mathrm{dec}) ;[\alpha]_{\mathrm{D}}^{23}+108^{\circ}\left(c 0.5, \mathrm{CHCl}_{3}\right)$; UV $\lambda_{\mathrm{max}}^{\mathrm{MeOH}} \mathrm{nm}(\varepsilon) 275(14,500)$; high resolution MS 578.322 (Calcd for $\left.\mathrm{C}_{30} \mathrm{H}_{48} \mathrm{~N}_{2} \mathrm{O}_{8}: 578.320\right) ;{ }^{1} \mathrm{H}$ NMR $\left(\mathrm{CDCl}_{3}\right) \delta 7.36(1 \mathrm{H}, \mathrm{d}, J=1.8 \mathrm{~Hz}, \mathrm{H}-19), 6.66(1 \mathrm{H}$, dd, $J=1.6$ and $1.8 \mathrm{~Hz}, \mathrm{H}-17), 5.60(1 \mathrm{H}, \mathrm{qd}, J=1.1$ and $8.5 \mathrm{~Hz}, \mathrm{H}-9), 1.58\left(3 \mathrm{H}, \mathrm{d}, J=1.1 \mathrm{~Hz}, 8-\mathrm{CH}_{3}\right)$, $1.26\left(3 \mathrm{H}, \mathrm{d}, J=7.0 \mathrm{~Hz}, 2-\mathrm{CH}_{3}\right)$.

Anal Calcd for $\mathrm{C}_{30} \mathrm{H}_{40} \mathrm{~N}_{2} \mathrm{O}_{9}$ : C 62.25, H 7.54, N 4.84.

Found:

C 62.13, H 7.68, N 4.65 .

\section{7-Decarbamoylherbimycin A (14)}

To solution of herbimycin A $(250 \mathrm{mg})$ in DMF $(3 \mathrm{ml}), \mathrm{CuCl}(150 \mathrm{mg})$ was added and treated in a similar manner with the preparation of 10 , to give a yellowish powder of $14,160 \mathrm{mg}(71.0 \%)$. TLC Rf $0.43 ; \mathrm{mp} 135^{\circ} \mathrm{C}(\mathrm{dec}) ;[\alpha]_{\mathrm{D}}^{23}+68^{\circ}\left(c 0.5, \mathrm{CHCl}_{3}\right)$; UV $\lambda_{\text {max }}^{\mathrm{MeOH}} \mathrm{nm}(\varepsilon) 267(22,000)$; high resolution MS 531.282 (Calcd for $\left.\mathrm{C}_{29} \mathrm{H}_{41} \mathrm{NO}_{8}: 531.283\right) ;{ }^{1} \mathrm{H}$ NMR $\left(\mathrm{CDCl}_{3}\right) \delta 7.18(1 \mathrm{H}, \mathrm{d}, J=2.0 \mathrm{~Hz}, \mathrm{H}-19)$, $6.65(1 \mathrm{H}, \mathrm{dd}, J=2.0$ and $2.0 \mathrm{~Hz}, \mathrm{H}-17), 5.98(1 \mathrm{H}, \mathrm{dd}, J=8.5$ and $11.5 \mathrm{~Hz}, \mathrm{H}-5), 5.60(1 \mathrm{H}, \mathrm{qd}, J=0.9$ and $10.0 \mathrm{~Hz}, \mathrm{H}-9), 4.40(1 \mathrm{H}, \mathrm{dd}, J=2.0$ and $8.5 \mathrm{~Hz}, \mathrm{H}-6), 4.22(1 \mathrm{H}, \mathrm{d}, J=2.0 \mathrm{~Hz}, \mathrm{H}-7), 1.54(3 \mathrm{H}, \mathrm{d}$, $J=0.9 \mathrm{~Hz}, 8-\mathrm{CH}_{3}$ ).

Anal Calcd for $\mathrm{C}_{28} \mathrm{H}_{41} \mathrm{NO}_{8}$ : C 65.50, H 7.78, N 2.64. Found:

C 65.38, H 7.99, N 2.51 .

\section{7-Decarbamoyl-8,9-epoxyherbimycin A (15)}

To a solution of $5(250 \mathrm{mg})$ in DMF $(3 \mathrm{ml}), \mathrm{CuCl}(150 \mathrm{mg})$ was added and treated in a manner similar to that described above, to give a yellowish powder of $15,130 \mathrm{mg}(57.0 \%)$. TLC Rf 0.41 ; $\mathrm{mp} 115^{\circ} \mathrm{C}(\mathrm{dec}) ;[\alpha]_{\mathrm{D}}^{23}+53^{\circ}\left(c 0.5, \mathrm{CHCl}_{3}\right)$; UV $\lambda_{\mathrm{max}}^{\mathrm{MeOH}} \mathrm{nm}(\varepsilon) 266(18,700)$; high resolution MS 547.277 (Calcd for $\left.\mathrm{C}_{28} \mathrm{H}_{41} \mathrm{NO}_{9}: 547.278\right) ;{ }^{1} \mathrm{H}$ NMR $\left(\mathrm{CDCl}_{3}\right) \delta 7.33(1 \mathrm{H}, \mathrm{d}, J=2.0 \mathrm{~Hz}, \mathrm{H}-19), 6.59(1 \mathrm{H}$, dd, $J=1.8$ and $2.0 \mathrm{~Hz}, \mathrm{H}-17), 5.97(1 \mathrm{H}, \mathrm{dd}, J=10.0$ and $10.0 \mathrm{~Hz}, \mathrm{H}-5), 4.48(1 \mathrm{H}, \mathrm{d}, J=10.0 \mathrm{~Hz}, \mathrm{H}-6)$, $2.95(1 \mathrm{H}$, br s, $\mathrm{H}-7), 1.27\left(3 \mathrm{H}, \mathrm{d}, J=1.8 \mathrm{~Hz}, 8-\mathrm{CH}_{3}\right)$. 


\section{Acknowledgment}

The authors wish to thank Mrs. M. Yoshida, Tokyo Research Laboratories, Kyowa Hakko Kogyo Co., Ltd., for NMR spectroscopy and Miss Y. HiroKAWA, The Kitasato Institute, for the animal experiments. This work was supported by funds from The Japan Keirin Association.

\section{References}

1) Ōmura, S.; Y. Iwai, Y. Takahashi, N. Sadakane, A. Nakagawa, H. Öiwa, Y. Hasegawa \& T. Ikai: Herbimycin, a new antibiotic produced by a strain of Streptomyces. J. Antibiotics 32: 255 261, 1979

2) Duros, J. \& M. Suffness: New antitumor substances of natural origin. In Cancer Treatment Review. Vol. 8, pp. 63 87, Academic Press, New York, 1981

3) Ōmura, S.; A. Nakagawa \& N. Sadakane: Structure of herbimycin, a new ansamycin antibiotic. Tetrahedron Lett. 1979: 4323 4326, 1979

4) Furusaki, A.; T. Matsumoto, A. Nakagawa \& S. Ōmura: Herbimycin A: An ansamycin antibiotic; X-ray crystal structure. J. Antibiotics 33: $781 \sim 782,1980$

5) Deboer, C.; P. A. Meulman, R. J. Wnuk \& D. H. Peterson: Geldanamycin, a new antibiotic. J. Antibiotics 23: 442 447, 1970

6) Sasaki, K.; K. L. Rinehart, Jr., G. Slomp, M. F. Grostic \& E. C. Olson: Geldanamycin. I. Structure assignment. J. Am. Chem. Soc. 92: 7591 7593, 1970

7) Tanida, S.; T. Hasegawa \& E. Higashide: Macbecins I and II, new antitumor antibiotics. I. Producing organism, fermentation and antimicrobial activities. J. Antibiotics 33: 199 204, 1980

8) Muroi, M.; K. Haibara, M. Asai \& T. Kishi: The structure of macbecin I and II, new antitumor antibiotics. Tetrahedron Lett. 21: 309 312, 1980

9) Arcus, C. L. \& H. E. Strauss: The addition of bromine to (+)-1-phenylallyl alcohol and the oxydation of the (+)-dibromo alcohol. J. Chem. Soc. 1952: 2669 2671, 1952

10) ARita, H.; N. Ueda \& Y. Matsushima: The reduction of chlorodeoxy sugars by tributyltin hydride. Bull. Chem. Soc. Jpn. 45: 567 569, 1972

11) Ōmura, S.; K. Miyano, A. Nakagawa, H. Sano, K. Komiyama, I. Umezawa, K. Shibata \& S. SatsumaBAYASHI: Chemical modification and antitumor activity of herbimycin A. 8,9-Epoxide, 7,9-cyclic carbamate, and 17 or 19-amino derivatives. J. Antibiotics 37: 1264 1267, 1984

12) Winstein, S. \& R. E. Buckles: The role of neighboring groups in replacement reactions. J. Am. Chem. Soc. 64: 2780 2790, 1942

13) Hardy, W. B. \& R. B. Fortenbaugh: The replacement of bromine by chlorine in aromatic compounds. J. Am. Chem. Soc. 80: 1716 1718, 1958

14) Bonner, G. T.; E. J. Bourne \& S. McNally: Dealkylation and deacylation of carbohydrate derivatives with boron trichloride and boron tribromide. J. Chem. Soc. 1960: 2929 2934, 1960 